\title{
The Social Construction of Disaster: Ondoy (Ketsana) in the Context of Sagrada Familia and Inquirer.net
}

\author{
Dindo P. Café ${ }^{1}$ \\ ${ }^{1}$ University of the Philippines Manila, Manila, Philippines \\ Correspondence: Dindo P. Café, University of the Philippines Manila, Padre Faura Street, Ermita, Manila, \\ Philippines. E-mail: dpcafe@post.upm.edu.ph
}

Received: January 13, 2012

Accepted: April 25, $2012 \quad$ Published: August 1, 2012

doi:10.5539/ass.v8n10p45

URL: http://dx.doi.org/10.5539/ass.v8n10p45

\begin{abstract}
Generally, studies on disaster in the field of social science are plain descriptions of the phenomenon and subjects are simply regarded as victims and rescuers. It is observable that there is neglect for theory generation and methodological expansion. These limitations serve as impetus for this research endeavor. Primarily, the aim of this research is to elicit theoretical and methodological contributions to the field of Sociology. In broad stroke, the inquiry centers on the social construction of disaster among the members of Sagrada Familia and Inquirer.net. This paper contends that there is an array of contexts that can essentialize the analysis of Ondoy (international name: Ketsana). Thus, Ondoy is not a natural phenomenon but a social construction. In conclusion, this paper highlights its theoretical contribution to social constructivism and its implications to problem-specific, community-based and participatory approaches in community engagement.
\end{abstract}

Keywords: social construction, disaster, Sagrada Familia, Inquirer.net, natural calamity, mishap and sakuna, tragedy and trahedya, evacuation and bakwet/bakwetan, assistance and tulong, rebuilding, hard work and sipag, paghahandang ispirituwal

\section{Overview of the Study}

The disasters that devastated several communities in the Philippines over the years are medium in which natural and social conceptions of the phenomena can be delineated. The construction of a phenomenon as natural and social is an epistemological process. The predominance of a discourse in molding descriptions of a phenomenon conceals its real meaning, thus constrains a holistic perspective. There is a need for a critical stance on the ways disasters are conceptually represented in literatures. Generally, there are two corollary questions purported by this exploration: (1) Are disasters social? (2) What are the social constructions of disaster? This paper argues that disasters are social phenomena anchored within the lives of the people and their social environment. Specifically, the paper aims to: (1) Know the concepts of Ondoy among the members of Sagrada Familia; (2) Know the representations of Ondoy in the articles of Inquirer.net; and (3) Identify the common concepts of Ondoy among the members of Sagrada Familia and Inquirer.net.

This paper limits its inquiry on the concepts of Ondoy from the perspectives of Sagrada Familia and Inquirer.net. This seeks to introduce multiplicity of meanings associated to Ondoy. This is an attempt to demonstrate that the meanings socially appropriated to Ondoy are not homogeneous but rather fragmented. Also, this invokes the contextualization of Ondoy within a particular social setting.

\section{Review of Related Literature}

This section examines various literatures that articulate concepts of disaster. The review of literatures stresses several points. First, it examines the concepts of disaster from the perspectives of several authors. Second, it discusses the notion of disaster from a social constructivist perspective. Third, it presents the themes related to disaster.

\subsection{What Is a Disaster? A Sketch of the Existing Concepts of Disaster}

Disaster is a complex term to define. It is a concept that is continuously defined and re-defined by experts in the academe, media, state, and even of the church. However, the intention to conceptualize disaster remains problematic. It has been a challenge among experts to lump into one perspective the varied and multifarious nuances of disaster. In fact, positivists failed to elicit generalization on the concept of disaster. It remains illusory 
to construct an objective or universal meaning of disaster. This paper capitalizes on the abovementioned limitation of a positivist perspective on disaster. This argues that disaster can only be defined by considering its social context. This means that the conceptualization of disaster should be based on different aspects such as the society where it happens, the people who experience it, the frame of mind of the experts in the academe and media.

The article of David Alexander (in Perry and Quarantelli, 2005:25) discusses the different meanings of disaster derived from experts who articulated the concepts. Based on the article,

Gilbert (1998:11) regarded it, among other things, as the passage to a state of uncertainty. Fritz (1961) interpreted disaster as a state in which the social fabric is disrupted and becomes dysfunctional to a greater or lesser extent. Fischer (2003: 94) suggested that "what disaster sociologists actually study is social (structure) change under specialized circumstances."

The abovementioned definitions according to Alexander are very tentative and mostly rather specific perspectives on disaster. These concepts are problematic in other fields such as geophysics and engineering. Also, these concepts of disaster are equally ambiguous in the field of Sociology. The crosscurrents of theoretical formulations in Sociology are not captured by one overarching definition of disaster. The themes presented by Alexander downplay other Sociological perspectives of disaster.

A more profound definition of disaster is discussed in another literature. Rohit Jigyasu (in Perry and Quarantelli, 2005:107) wrote an article entitled "Defining the Definition for Addressing the Reality", and quoted Gilbert (1998:11) for his three paradigms of disaster. According to the article,

First, disaster is a duplication of war (catastrophe can be imputed to an external agent; human communities are entities that react globally against aggression). Second, disaster is an expression of social vulnerabilities (disaster is the result of underlying community logic, of an inward and social process). Third, disaster is an entrance into a state of uncertainty (disaster is tightly tied into the impossibility of defining real or supposed, especially after the upsetting of the mental frameworks we use to know and understand reality).

These paradigms according Jigyasu (in Perry and Quarantelli, 2005:107) operate as frame in the analysis of disaster as an objective phenomenon. Moreover, the representation of disaster as source of irresoluble problems is profoundly propagated by the article. This makes the concept of disaster all the more difficult to conceptualize. The aforementioned author stresses the conceptual intricacies of a phenomenon. He firmly pursues theoretical questions:

What is this reality, after all? Is there anything that we can say is universally "real" or is reality itself a construct, specific to shared values, thinking processes and visions of the groups of people-which we call communities?

Substantially, the questions direct to a particular paradigm. Jigyasu is critical to the limitations of an objective conceptualization of disaster to capture the holistic reality that encompasses it. There is a compelling theoretical inquiry that invites revision of the meanings associated to disaster. This serves as challenge to social scientists to tease out indigenous concepts based on the perspective of people who experience the phenomenon. This paper affirms a social constructivist point of view in describing the context of Ondoy among the members of Sagrada Familia and Inquirer.net.

In one particular case Jigyasu (in Perry and Quarantelli, 2005:107) examines "eastern thought" on the concepts of "space" and "time" in relation to disaster. Jigyasu cited Galtung (1979) and Vatsayan (1994) as social scientists who define "space" differently. According to them,

In eastern thought, physical manifestation gets directly linked to the understanding at sub-conscious level, which gives shape and deeper meaning to the landscape. Such a landscape is constructed through symbolic representations, sometimes even representing the whole cosmos at the micro level.

This notion of "space" is conceptually distinctive to the common western concept of space as geographical and physical entity. In the same vein the concept of "time" is defined in the East differently. According to the authors,

"Eastern" notion of time is cyclic; an endless cycle of birth and death, creation and destruction, implying that there is no beginning or an end. 
Jigyasu (in Perry and Quarantelli, 2005:107) describes this perspective as contradictory to the unilinear concept of time. He states that "eastern thought" concept of time is cyclical. This posits that disaster is a "cycle of creation and destruction". At a theoretical sense, this variation in conceptual constructs of time, space and disaster prove that a phenomenon can be viewed at different perspectives. Alexander (2005) argues:

However, disaster is not defined by fixed events, or immutable relationships, but by social constructs, and these are liable to change.

The theoretical challenge of Alexander is obvious. He basically presses for social constructs of disaster. Alexander (2005) posits that disaster is a mindset, fixity of opinions or states of mind created by events. This mode of defining disaster clearly shows the use of "symbolism" in the process of concept formation. Specifically, he cites Kroll-Smith and Couch (1991) who strongly recognize the function of symbols in the conceptualization process of disaster. According to them,

Any other collective view of disaster, whether it is a rigid one such as a mindset or a more pluralistic one, is achieved by converting complex events into symbolic ones.

This point of view highlights the pivotal role of language in the formation of deeper and broader concept of disaster. This perspective emphasizes the power of language to orchestrate the construction of meanings by the people who experience the phenomenon.

Alexander (2005) discusses further the perspective of symbolism. According to him symbolism is categorized into three, namely:

Functional such as symbolic of physical or social process; linguistic like a convenient form of notation; and as an allegory or parable such as with a tale to tell, possibly of a moral kind.

The functions of symbolism discussed by Alexander offer a rich prospect in the inquiry on disaster. It is an imperative to consider symbolism in studies that analyze salient themes in a particular meaning system. This paper is directed by this perspective, affirming the crucial role of language in making sense of Ondoy.

Dynes and Rodriguez (2005) made a study on storm Katrina in the United States and found out multiple meanings of the phenomenon. Based on this study there are themes of Katrina that are implicated in televisions. According to the authors, the salient themes in the news are: finding damage, finding death, finding help, finding authority, and finding bad guys. In the analysis of Alexander (2005) on studies about disasters, he generated themes such as the enormity of the event; the paradoxical beauty — or at least the visual novelty of destruction; the courage of rescuers; humanity reasserted amid terrible physical destruction; the pathos of charity and solidarity; the triumph of moral purpose over arbitrariness or malevolence; the value of determination and staying power; and the wonder of an indomitable spirit.

\section{Methodology}

\subsection{The Research Locale}

This research was conducted in Sitio Ronggot, Barangay Lecheria, nestled in the coastal area of Laguna de Bae in Calamba City, Philippines. The community is composed of more or less eighty families. The inhabitants rely on fishing and farming vegetables for their daily subsistence. Ronggot started as a community with seven migrant families from Olivete, Pangasinan, Philippines who settled in an uncultivated agricultural and coastal area in 1958 to spread out the mission of Sagrada Familia. Most of the people in Ronggot are members of Sagrada Familia that is one of the millenarian groups that venerate Doctor Jose Rizal, deemed Philippine National Hero as Holy God and Savior. The Rizalistas opted to settle in Laguna de Bae with a belief that the place is a promise land and a symbol for salvation of their souls.

\subsection{Research Methods}

This paper used mix methods in data gathering. First, articles published by Inquirer.net were reviewed to distill themes related to Ondoy. The ultimate purpose of the review is to identify the representations of Ondoy in the Inquirer.net. Second, observations were conducted upon the resettlement of Rizalistas in Ronggot after three months of evacuation due to flooding brought by Ondoy. Observation was instrumental in providing deep descriptions of the damages that resulted from Ondoy and daily activities of the Rizalistas as they struggle to source out for their livelihood. Third, in-depth interviews were conducted with elders and religious leaders to elicit concepts of Ondoy. In methodological sense, the paper used triangulation. This strategy in research is essential in the validation of data gathered that constitute a deeper grasp on the subjects and issues under investigation. 
Observation of the community is instrumental in describing the condition of the members of Sagrada Familia. Series of observations was done in order to have a deeper characterization of the subjects. Basically, observations were conducted to capture the daily activities of the people and their physical environment. The damages of Ondoy on the physical environment and properties of the Rizalistas were keenly observed. Moreover, through observation I was able to describe how Rizalistas recovered their source of living through fishing and vegetable production.

The interviews conducted were based on the categories of information in accord with the research problem. In general, the sensitizing themes of the interviews are: (1) concepts of Ondoy, (2) factors that shape their concepts of Ondoy, (3) effects of Ondoy to the members of Sagrada Familia, (4) assistance/aid received by the Rizalistas during Ondoy, (5) institutional shortcomings during Ondoy, and (6) experiences of Rizalistas in the evacuation center.

\section{Theoretical and Conceptual Framework}

This paper uses a combination of theories. First, ethnomethodology of Harold Garfinkel is applied to the process of forming concepts of Ondoy. The indigenization of the concepts of Ondoy is basically in parallel with the basic arguments of ethnomethodology. In a major work, Harold Garfinkel (1967) presents the core theoretical stance of ethnomethology.

For ethnomethodology the objective reality of social facts, in that, and just how, it is every society's locally, endogenously produced, naturally organized, reflexively accountable, ongoing, practical achievement, being everywhere, always, only, exactly and entirely, members' work, with no time out, and no possibility of evasion, hiding out, passing, postponement, or buy-outs, is thereby sociology's phenomenon.

As a way of explication Ritzer (1996) articulates that ethnomethodology,

Sees the objective reality of social facts as an "ongoing accomplishment of the concerned activities of everyday life.”... in everyday situations individuals invoke or recognize social facts, such as taken-for-granted norms and values, that interpret the meaning of the situation for them. When they make sense of the situation by recognizing implicit social norms, individuals are constructing social reality... they are ordering their experiences so that they are in line with what we consider the everyday social world to be like... ethnomethodological studies "analyze everyday activities as members' methods for making those same activities visibly-rational-and-reportable-for-all-practical-purposes, that is 'accountable' as organizations of common place everyday activities. (p.262)

However, this study centers on a wider perspective of the Rizalistas on Ondoy. The process of indigenization of the concepts of Ondoy is treated deeper by invoking other theories that will explain the dynamics and mechanism of the process. Theories that elucidate the interplay of emic and etic perspectives in shaping the concepts of Ondoy among Rizalistas were applied in this study. According to Pierre Bourdieu the social structure plays a crucial role in the quality of social interaction of people within the society. According to him,

the objective structures... form the basis for... representations and constitute the structural constraints that bear upon interactions; but, on the other hand, these representations must also be taken into consideration particularly if one wants to account for the daily struggles, individual and collective, which purports to transform or preserve these structures (Bourdieu, 1977).

The theoretical statement of Bourdieu sketches the reciprocal interplay between agency and structure. An individual has the power to shape the society and on the other hand the society shapes people. This is the same argument presented by Georg Simmel. According to Simmel,

People produce culture, but because of their ability to reify social reality, the cultural world and the social world come to have lives of their own, lives that come increasingly to dominate the actors who created, and daily re-create, them (Simmel, 1955).

The same is true with the theory of Anthony Giddens on "structuration" that pushes for the integration of agency and structure. According to Giddens (1991):

The constitutions of agents and structures are not independent of one another; the properties of social systems are seen as both medium and outcome of the practices of actors, and those system properties recursively organize the practices of actors. 


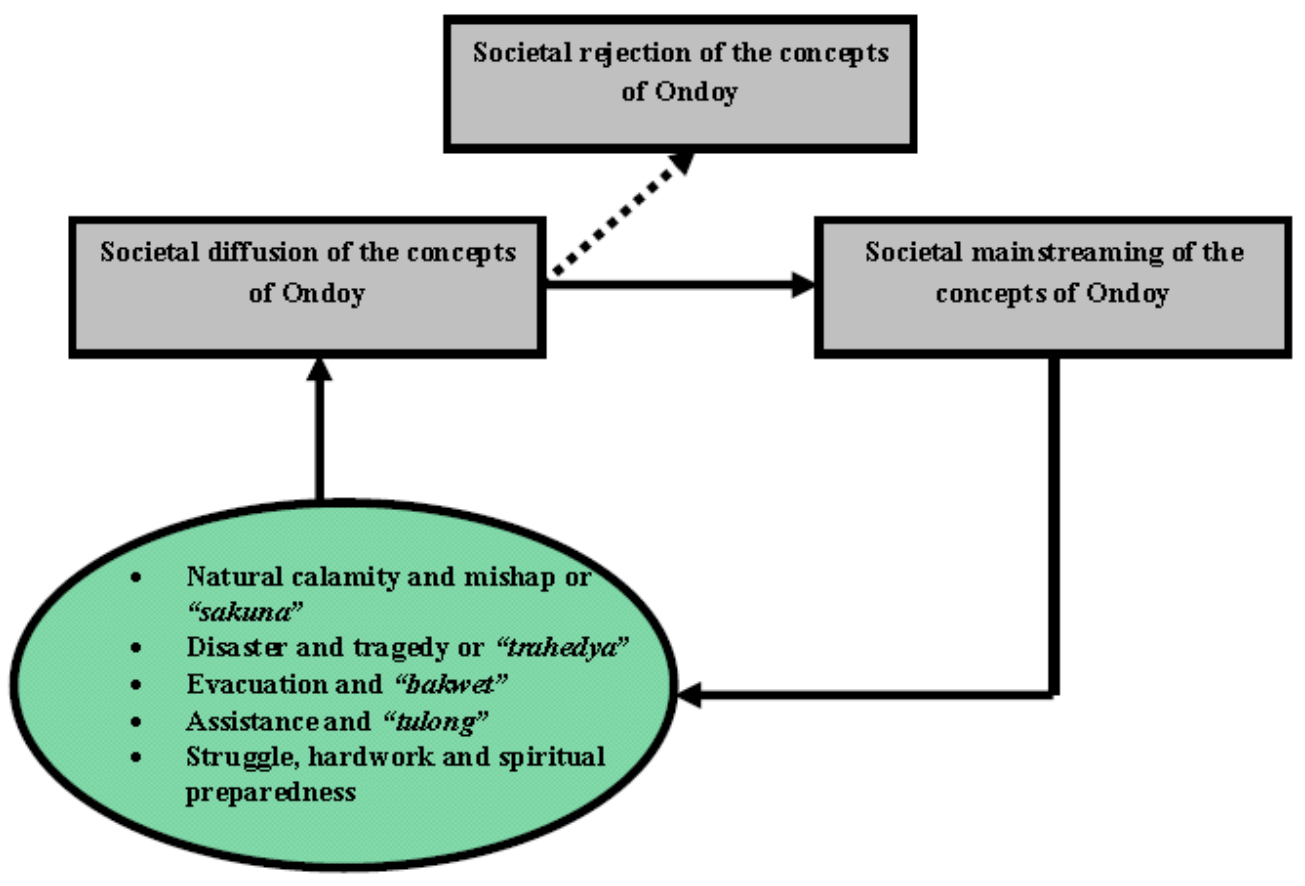

Figure 1. Conceptual framework

The conceptual framework (see Diagram 1) is drawn from the theories discussed in the preceding part of this paper. This is a heuristic device that illustrates the integration of the objective and subjective perspective on Ondoy. The theoretical intention of this paper is to elicit concepts of Ondoy among the members of Sagrada Familia and Inquirer.net within the context of two processes. The concepts of the storm Ondoy are mainstreamed as they are widely diffused throughout the society. On the other hand, rejection to the diffusion process results to retention of old concepts.

\section{Results and Discussion}

\subsection{Ondoy as a Natural Calamity and Mishap, and "Sakuna"}

One prevalent theme in the articles of Inquirer.net is the representation of Ondoy as a natural calamity. The general notion propagated in the articles figures out Ondoy as a natural phenomenon. The onset of the storm Ondoy in different provinces all over the Philippine archipelago was highlighted in several articles. According to Dizon (PDI, 09/25/09),

Ondoy was spotted 130 kilometers northeast of Virac, Catanduanes packing maximum winds of 65 kilometers per hour near the center with gustiness of up to 80 kilometers per hour, the Philippine Atmospheric, Geophysical and Astronomical Services Administration (Pagasa). The weather system was moving west-northwest at 11 kilometers per hour. Pagasa raised public storm signal warning number 2 in Catanduanes, Camarines Norte, Camarines Sur, and Polillo Island and signal number 1 in Albay, Burias Island, Quezon, Marinduque, Rizal, Bulacan, Aurora, Nueva Ecija, Nueva Vizcaya, Quirino, and Isabela. Ondoy is expected to be 130 kilometers west-northwest of Dagupan City Saturday afternoon until Sunday afternoon. Pagasa said that Ondoy was expected to enhance the southwest monsoon, bringing rains over Central and Southern Luzon as well as in the Visayas.

A day after the announcement of Pagasa, on September 26, 2009 the storm Ondoy landed on other provinces including Metro Manila. Some places in Metro Manila were inundated due to heavy rains. In the article of Tandoc and Evangelista, (PDI, 09/26/09) they wrote,

Storm warning signal number 1 was hoisted over Isabela, Mountain Province, Ifugao, Benguet, La Union, Ilocos Sur, Laguna, Cavite, Batangas, Mindoro Provinces, Lubang Island, Marinduque, Camarines Norte, Bataan, Metro Manila and the rest of Quezon Province. President Gloria Macapagal-Arroyo declared a state of calamity in Metro Manila and in 25 Luzon provinces as heavy rains brought by the storm caused the worst flooding seen in the 
capital in some 20 years. Close to 2,000 people in different areas in Metro Manila were forced to flee their homes and major thoroughfares were closed to traffic.

However, flooding is not isolated to Metro Manila. There are also floods in different towns in the province of Laguna, those that are located in the coastal areas of Laguna de Bae. The upsurge of water in this lake swamped many communities. According to Uy, (PDI, 10/02/09),

Manda, the Laguna Lake Development Authority (LLDA) chair, identified areas including Sta. Rosa, Calamba, San Pedro, Los Baños and Paete seriously affected by flood. Three days after rains brought by Ondoy inundated the capital, Laguna de Bae's water level was at 13.82 meters on the agency's monitoring scale, according to Manda. "The water level may break its all-time record in 1919 if water continues to flow into the lake." The lowest water level recorded by the LLDA was 10.19 meters in 1969. The average increase in the lake level was at 28 meter a month. But in the last three months of this year alone, the water level rose by 2 meters, or .67 meter a month. The water went up by 1.2 meters after Ondoy brought rains that submerged a large swath of the capital and neighboring provinces.

In another article written by Cinco at Ramos (PDI, 10/04/09) the same phenomenon was described. According to them,

Parts of Calamba City and the towns of San Pedro, Biñan, Sta. Rosa, Cabuyao, Los Baños, Bay, Victoria, Pila, Sta. Cruz, Lumban, Kahayan, Paete, Siniloan, Mabitac, Sta. Maria, Pangil and Pakil remained flooded. The average water level from July to September ranged between 11.8 to 12.6 meters. Its water level was at 13.82 meters three days after rains brought by tropical storm Ondoy submerged Metro Manila and nearby provinces. Manda said the originally 90,000-hectare lake crept into the lakeshores by 10,000 hectares as of their latest monitoring. "It [water level] plays between 13.9 to 14 meters," he said as of Saturday morning. The lake's water level hit an all-time record of 14.62 meters in 1919.

Ondoy is considered as a natural calamity by Inquirer.net. The articles stressed the onset of the storm and massive flooding in different areas in Luzon. Semblance with the experiences of the members of Sagrada Familia is noticeable. Based on my interviews with the people in Ronggot, in the City of Calamba, the place was flooded. According to Betty,

Yung Ondoy baha ang dala. . . Unti unting lumalaki ang tubig. Noong umaga mga dalawang metro na ang taas ng tubig. Noong hapon hindi pa rin tumitigil ang paglaki ng tubig, nagpasabi na si Kapitan sa kanyang mga tanod na magsilikas na ang mga tao kasi magbubukas daw ang mga dam ng tubig. Ondoy brought flood. . . The water level rose gradually. In the morning, the water level reached to two meters. During the afternoon, the water continuously rose, and the Barangay Captain already sent his watchmen to direct the locals to evacuate in fear of water release from dams.

Manong Eufemio shared the same experience when I interviewed him. He lucidly described Ondoy as storm with flooding. According to him,

Noong una ang Ondoy hindi masyadong nakakatakot. Ang Ondoy hindi malakas ang hangin, kundi ang tubig lang ang umalsa; lumalim. Bagamat ganoon, medyo natakot din kami, yong mga bata pinalikas ko sila. Kalamidad nga, baka anong magyari. Ibinalita pa sa radyo na aalpasan pa ang dam sa Kaliraya, mas lalong madadagdagan ang tubig. Sa bahay ko nasa tuhod na ang tubig di lalong lalaki. Ondoy was not scary at its onset. The wind was moderate but, the water rose; it was deep. I was scared and told my children to evacuate. It was a calamity, anything may happen. There was a radio announcement of a pre-emptive water release of Kaliraya dam that will raise the water level. This will increase the knee-deep flood in my house.

The consonance of the themes between the articles in Inquirer.net and my interview accounts of Betty at Manong Eufemio is noticeable. First, Ondoy was described as storm. Second, Ondoy has brought flooding to coastal communities.

During interviews, I was vigilant to know how the locals view Ondoy in a deeper sense. My concern was to know their views on Ondoy in relation to environmental issues that wrestled Laguna de Bae. I am aware of the basis of my perspective. This is coming from a technical and academic discourse derived from books and other resource materials, opinions of experts, scientific community and other sources. However, in my interviews with the members of Sagrada Familia, they have neutral articulations on the relation of Ondoy to environmental issues. 
What is commonly stated during interviews is the five or ten year cycle of storm and flooding in their community. This view is parallel to the description of Jigyasu (in Perry and Quarantelli, 2005:107) on the Eastern perspective of time which is cyclical. It is a natural phenomenon in their community to experience storm and flood every five or ten years. The members of Sagrada Familia view no relation of the flooding in Laguna de Bae to the massive logging and soil erosion from the tributary rivers upland of the lake. Also, they do not associate flooding with the high level of sedimentation brought by massive fish culture and industrial wastes in Laguna de Bae.

In my succeeding interviews, a salient perspective on Ondoy among the members of Sagrada Familia has emerged. The worldview of Rizalistas on Ondoy is unique from the representations in the Inquirer.net and beyond the technical and scientific paradigms. According to the members of Sagrada Familia, Ondoy is a spiritual experience. According to Manang Gloria, Ondoy is a sakuna or mishap under God's divine power that is uncontainable by humans. In her statement, Ondoy is,

Isa itong paalala ng diyos. Ang diyos ay kinakalimutan na, kaya ang inang kalikasan, siya ang nagiging mensahe, lalo ang tag ulan. Ang mensahe, kahit saan na hindi dati nalulubog sa ulan ay malulubog. Totoo ito kasi kahit sa Amerika nangyayari ito. Ito ay senyales ng pagdating $n g$ "pangatlong eye." Nangangahulugan na mas matindi ito, tulad nga ng mga nangyayari. This is a sign from God. God is almost forgotten, thus made mother nature, especially heavy rains as his message. The message is; places that are not usually flooded will be inundated. This is true because even America is not spared from flooding. This is the sign of the coming of the "third eye." This means even more grievous like what is happening.

Also, the eldest member of the Sagrada Familia expressed the same belief in reading Ondoy as a phenomenon. According to Manang Bebeng,

Kinompas ng Mahal na Birhen na tulad ng lumang Calamba, ang Aplaya ay lulubog sa Laguna de Bae. Lahat ng sinabi sa amin ng spiritu ay nagaganap. Ang nagdaan na bagyo ay siya nang "pangatlong eye." Ang "unang eye" ay ang pagsakop sa Pilipinas ng mga Hapon. Ang "pangalawang eye" ay ang pagbalik ng mga Amerikano tatlong taon pagkatapos ng pangbobomba sa Pilipinas. At ang "pangatlong eye" ay napakalungkot. Ito na ang paghuhukom ng panginoon. Ito na daw ang simula, senyales ng katapusan ng mundo. Ang mga elemento $n g$ kalikasan, tulad $n g$ hangin, bagyo, ulan, ay pinapakilos $n g$ panginoon. It is foreordained by the Blessed Virgin that similar to ancient Calamba, Aplaya will submerged in Laguna de Bae. All the spiritual messages will happen. The storm that passed was the "third eye." The "first eye" was the Japanese invasion of our country. The "second eye" was the reinstatement of the Americans three years after bombing the Philippines. The "third eye" was the most sorrowful. This is the judgment day of our God. This is the beginning, a sign for the end of the world. The elements of nature such as wind, storm, and rain are mobilized by God.

This is an atypical perspective on the explanations of storm and flooding. As a devout Christian, I have a share of religious messages of apocalypse and Armageddon, but the concept of three "eye" is distinctive. This is divergent to the meaning attached to the three "eye" or an eye in the middle of a triangle as "all seeing eye." I now realized the importance of this symbol to the members of Sagrada Familia.

I have reckoned more epiphanies as members of Sagrada Familia describe their interventions to natural calamity. The concepts of kabutihan or goodness, pagkakaisa or unity, and paghahandang ispirituwal or spiritual preparedness are key values preached by Manang Bebeng. According to her,

Kaya dapat hindi na tayo gagawa ng masama. Gawin natin ang mabuti. Sana huwag na tayo mabalik sa masama... Pagkakaisa. Kahit saan ka man na relihiyon, respetuhin mo ang ibang paniniwala. Kasi iisa lang naman ang diyos natin. Tatlong persona pero iisang diyos lang. Si Rizal, si Apo Ignacio, at si Hesus ay iisa lang. . . Ang iba kasi materyal na bagay lang ang tinitingnan. Kailangan talaga ang paghahanda na ispirituwal. We should not do evil. Let us be good. Let us not return to evil. . Unity. Everyone should respect other religions. We have only one god. It is Holy Trinity. Rizal, Apo Ignacio, and Jesus Christ are one. . . Others just give importance to material things. Spiritual preparation is needed.

I was all the more enlightened on the concepts of Ondoy among the members of Sagrada Familia when Manang Gloria shared to me their rituals that will save them from typhoons and floods. This notion of prevention is divergent to techniques promoted by experts in the scientific community. The members of Sagrada Familia have faith on spiritual preparation as prevention to natural calamity. According to Manang Gloria, 
Nag aalay o naghahain kami ng pagkain, tulad ng manok, tinapay, malagkit at prutas. Ang para sa hangin ay binabalot at isinasabit sa kahoy. Ang para sa tubig ay nilulubog. Ang sa apoy, ay susunugin. Ang sa lupa, ibabaon. Ito ay ginagawa tuwing unang lingo ng Mayo. We are offering or preparing food such as chicken, bread, glutinous rice and fruits. Offerings to wind are hanged on trees. Offerings for water are submerged in the lake. Offerings to fire are burned. Offerings to land are buried. The rituals are done every first week of May.

The concept of Ondoy that is unique based on my interviews is the consideration of the phenomenon as a mishap. This concept is different from the notion of tragedy that I will discuss in the succeeding chapter of this paper, for this captures the religious aspect of the phenomenon. Tragedy was conceived as a negative effect of Ondoy to their environment, properties, livelihood and their spirituality. On the other hand the concept of mishap capitalizes on the uncontrollable character of Ondoy. This emphasizes the incapacity of human beings to control the phenomenon as it is solely under the will of God and the only intervention that people are capable of doing is prayer. Clearly, this is a religious point of view on Ondoy as a phenomenon. This notion is anchored on the religious beliefs of the members of Sagrada Familia.

\subsection{Ondoy as a Disaster or Tragedy and "Trahedya"}

In my interviews, the concept of tragedy emerged in relation to Ondoy. In my analysis the concept of tragedy is based on the damages brought by Ondoy. The members of Sagrada Familia strongly associate the concept of tragedy to the storm Ondoy. Specifically, tragedy for them refers to the damages of their properties and barangay electric system, and disruption of their daily sources of livelihood. According to Betty,

(Ang Ondoy) Isang trahedya talaga. Kasi marami ang naapektuhan, tulad ng nasira ang mga bahay at kabuhayan. Mayroon pa ngang namatay. Dalawa ang patay na natagpuan sa may Igat. (Ondoy) is really a tragedy. It has tremendous effects such as damages on houses and sources of living. There are also recorded deaths. Two dead bodies were recovered in Igat.

The issue of death is also a major theme in Inquirer.net. An article discloses the number of casualties during the storm Ondoy. During the first countdown of the deaths, Evangelista (PDI, 09/27/09) stated that, at least 73 persons were killed by massive flooding after tropical storm Ondoy dumped the heaviest rainfall on Metro Manila. The number of casualties increases rapidly. In the article of Uy (PDI, 10/01/09), she reported that the death toll from Storm Ondoy rose to 280.

In a separate interview with Manong Eufemio, he narrated his concept of Ondoy as a tragedy. According to him,

Noong dumating na ang alon, yon na ang naging problema namin. Sira sira ang mga bahay. . . Problema ang pinagkukunan namin ng kabuhayan. Hindi na namin alam kung saan kukuha ng kangkong, kasi tinangay $n g$ alon. Pangalawa, itong aming wire ng kuryente, ng ilaw, nagkalagotlagot dala ng mga water lilly na dala ng tubig. When the waves came, that is our problem. Our source of livelihood became problematic. We did not know where to harvest water spinach as they were drawn away by waves. Second, the electrical wire system was damaged by water lillies because of the strong water current.

The concepts of tragedy and damages brought by Ondoy are also articulated in the articles of Inquirer.net. Presented in the aforesaid online newspaper are statistical calculations on the damages of properties and sources of livelihood due to Ondoy. According to Olchnodra (PDI, 09/28/09),

Farm lands in the Calabarzon (Cavite, Laguna, Batangas, Rizal, and Quezon) region suffered a combined P95 million in crop damage because of typhoon Ondoy according to initial reports from the region. Of the total crop damage, P85 million worth of rice was reported lost as well as P10 million worth of high value crops, Agriculture Undersecretary Emmanuel Paras said in a text message on Sunday.

A more tremendous damage was estimated in the article of David (PDI, 10/09/09). According to him the storm Ondoy has enormously affected the economy of the Philippines. He wrote,

The government has placed the economic impact of Storm Ondoy at P8.3 billion, derived mostly from estimates of damaged infrastructure, homes and crops, and the cost of rescue and relief operations... Using official reports from the National Disaster Coordinating Council, the Department of Education, Department of Agriculture, and other government agencies, an economist connected with a multi-lateral institution places the total economic damage at P14.9 billion. This estimate, he says, does not include losses suffered by the private sector, including those incurred by business closures and damage to smaller enterprises. His estimate includes 
losses of up to P2.5 billion in the housing sector; P88 million (which amount could reach up to P140 million) in "access cost of students" who were displaced from their schools which were converted into evacuation centers; and P290 million in "foregone revenues of the dead."

\subsection{Evacuation and "Bakwet/Bakwetan" During the Storm Ondoy}

The term bakwet is commonly used by the members of Sagrada Familia. This concept is local translation of the English word evacuate. The term originated from Pangasinan, and brought by Rizalistas when they migrated from Northern Luzon to Southern Tagalog. Based on my interview accounts, bakwet was led by the Barangay officials of Lecheria that has the jurisdiction of Sitio Ronggot. In the afternoon of September 26, 2009, when the water of Laguna de Bae was constantly rising, the members of the Peace and Order Council instructed the people to evacuate. The elementary school of Lecheria was used as a temporary shelter of the evacuees. Families, nineteen of them, were jam packed in small classrooms. Eighty-six families that reside in Ronggot were not all accommodated in the evacuation center. Some of them just stayed in their relatives and friends, and others have rented houses. The evacuation lasted for three months, from September 26, 2009 to December 26, 2009. As of the time of my fieldwork, there are some families that remained in their rented houses.

The theme of evacuation due to extreme flooding was also covered by Inquirer.net. In an article of Lapitan (PDI, 09/29/09), she reported that,

3,000 families in this city (Calamba) were evacuated to safe ground as floods spawned by typhoon Ondoy swamped this city... while the city's Action Center said 3,084 families or 15,765 individuals were already in 43 designated evacuation centers in the area. It added that so far, 4,598 families or 22,015 persons in this city either fled from the floods or lost property due to the floods spawned by typhoon Ondoy.

In another article written by Dizon (PDI, 10/10/09), he noted the plan to relocate people survivors of the storm Ondoy through the lead of the Department of Social Work and Development (DSWD). He pointed the protracted process of evacuation. According to him,

DSWD Secretary Esperanza Cabral yesterday said it could take a year for the government to relocate some 70,000 families affected by tropical storm Ondoy. . the government would need some P4.7 billion for the relocation of the evacuees. . . each housing unit would cost some $\mathrm{P} 75,000$. The affected families are mostly informal settlers in Laguna Lake, the Manggahan Floodway area and the Marikina River as well as other river banks that overflowed after Ondoy dumped a record amount of rainfall in the metropolis on September 26, killing nearly 300 people.

In my interviews of the members of Sagrada Familia, they presented an elaborate description of their experiences in the evacuation center or bakwetan. According to Manang Gloria, it was a miserable experience. It was difficult for them to sleep due to noisy and distractive environment. Usually, they can sleep around midnight. Another interviewee has the same experience. Betty described the evacuation center,

Ang gulo... Mahirap... Sa isang room ilan kayo, labing siyam na pamilya. Ang dami, minsan ang anak ng isang mag asawa ay walo, di sampo na sila sa isang pamilya. Ang iba sa labas, sa may upu-upuan nalang natutulog. Makalat, marumi kasi may mga bata. Tapos ang palikuran na ginagamit ay dalawang butas lang. Sa dami ng gumagamit, bago ikaw, pipila ka muna ng matagal. It was cluttered... It was difficult... There are nineteen families in a room. It was overcrowded; sometimes a couple has eight children, making them ten in a family. Others just stayed outside, slept on benches. The place was messy because of the babies. There are only two pit toilets, so you need to fall in line every time you need to use it.

Palumbarit (PDI, 2009) presented a more depressing story about the evacuees. In the title of his article "Duck pens shelter Laguna town evacuees" one can imagine the sacrifice experienced by the evacuees during Ondoy. According to him,

There are no walls or ceilings and instead of a floor, rice hull covers the ground and fills the air when wind blows or someone steps on it. This is a duck pen and home to four families who fled flooding in this town brought by Tropical Storm Ondoy. About 100 square meters, the structure that used to keep hundreds of ducks now provides shelter to the families, who could not return home because the flood hasn't subsided weeks after Ondoy left.

In the case of my subjects, men experience being bored in the evacuation center due to the disruption of their daily activities. According to Betty, 
Puro tambay lang ang nangyari sa bakwetan kasi wala ka namang gagawin doon, nakakainip. Kahit ang dami namin naboboring ako... Sabi ko nga mas maganda pa dito sa Ronggot kahit mag isa lang ako kasi may hanapbuhay. We just stand by doing nothing. Although we are many, it was boring. I said it is better here in Ronggot even if I am alone at least I have a livelihood.

Manong Eufemio also shared his similar experience in the evacuation center. Just like Betty, he missed the usual routine in a day. According to him,

Namimis ko ang lugar na ito, kasi iba ang kilos mo dito, iba ang kilos mo doon sa bakwetan. Buti nalang malapit naman, dito nalang muna kami ang mga lalaki pag gabi. Pinapasyalan na lang namin ang mga bata sa bakwetan. We missed the place because our activities are different here; it is different in the evacuation center. Fortunately, the place is proximate, that we stay here at night. We just visit our children in the evacuation center.

\subsection{The Assistance and "Tulong" to the Survivors of the Storm Ondoy}

The storm Ondoy brought negative as well as positive effects. I also heard good stories from the members of Sagrada Familia. According to Manong Eufemio, we are fortunate during the storm Ondoy because there was an increase in our fish catch. He narrated,

Bagamat ganoon meron ding kaunting kasayahan. Tulad ng lumabas ang maraming isda. Nanagana rin kami sa isda, nakawala sa mga fish cages, kaya ang aming kanti punong puno ng huli. Maganda sa amin, swerte kami. We found gratification with what happened. Fish are abundant coming from the cages, that our fishnets are full of catch. It good for us, we are really fortunate.

This is also the experience reported by Mallari (PDI,10/05/09) in his article entitled "Ondoy brings windfall to lake fishers". According to the article,

If there's a good side to Tropical Storm "Ondoy," it could be the tons of fish that needed little effort to catch and brought windfall to fishermen around the Laguna Lake. Rey Manangan, coordinator of the Pambansang Lakas ng Kilusang Mamamalakaya ng Pilipinas (Pamalakaya), said fishermen's average catch in the aftermath of Ondoy rose to 7.5 kilograms. It used to be 4 kilograms. Ondoy, Pamalakaya said, let out tons of bangus (milkfish), tilapia, and other types of fish from fish cages in the lake.

The stories of giving aid and assistance to the survivors of Ondoy have been part of the themes in the Inquirer.net. There are many stories that recognize the kindness of other people to the extent of losing their lives while rescuing victims of the storm. In the article "Ondoy volunteers, donors: Lifesaver to multitudes" the benevolence of our Filipinos has been acknowledged. According to the article,

They were lifesavers to the multitudes who struggled to keep their heads and hopes above water, whether against the torrents of destruction or the slow currents of despair. They were the volunteers and donors who, in countless ways, helped the battered populace and the nation's downcast spirit recover from the devastation wrought by Tropical Storm Ondoy. Parishes, schools, companies, and civic groups set up networks of relief-processing centers, where thousands of volunteers worked in shifts for weeks.

Another salient theme in the Inquirer.net is the donations of the international community to the victims and survivors of the storm Ondoy. In one of its articles released on November 22, 2009, the it has been reported that,

The European Commission, the European Union's executive branch, has allocated an additional $€ 7$ million (about P490 million) in humanitarian assistance for the victims of typhoons Ondoy.

In the province in Laguna, the local government shouldered the expenses for the medicines of patients who were inflicted with disease due to flooding. According to Cinco (PDI, 10/16/09),

Local authorities have announced they will buy medicine to help contain a possible outbreak of leptospirosis in this town, which has stayed flooded since Typhoon "Ondoy" devastated a large swath of Metro Manila and nearby provinces nearly three weeks ago.

Assistance has been a great help to the members of the Sagrada Familia especially during their stay in the evacuation center. There was a sufficient supply of food such as rice, noodles, can goods and water. Different organizations like Canossa Sisters, Saint Joseph College, Seventh-Day Adventist, the Local Government Unit (LGU) of Calamba City and DSWD; were active in giving relief goods. 
The assistance of the LGU of Calamba City was continued even after the evacuees resettled in Ronggot. Half sack of rice and financial assistance of 3,000 pesos were given to the evacuees during the storm Ondoy. They are grateful with the aid given to them; however there are criticisms on the way it was distributed. According to Manang Mareng,

May mali sa pagbibigay nila ng tulong. Dapat ang mga nawalan ng bahay malakilaki ang bigay sa kanila. Pero hindi, ang nangyari parepareho lang ang bigay. Tapos kung sino ang kaibigan ng mga namamahala yon ang nabibigyan. Samantala may mga nasiraan ng bahay tapos hindi nabigyan ng tulong. There was a problem in the distribution of assistance. Ideally, bigger assistance should be given to those who lost their homes. But, the aid was distributed equally... And then, those friends of the project implementers are the ones given the assistance. While there are those with wrecked houses but did not receive any aid.

This is also the comment of Manong Eufemio in his statement during my interview. According to him,

Hindi lahat nabigyan, kung sino pa ang sira ang bahay hindi pa nabigyan. Not all were given assistance; those whose houses were damaged and supposed to receive assistance were not given.

The members of the Sagrada Familia were emotional as they share to me the stories of their experiences regarding the assistance they have received from different donors. They are thankful to the help extended to them. However, the Rizalistas are clamoring for assistance to their source of livelihood. Alternative sources of income are needed by the community according to Manong Eufemio. A big boat that will serve as a community transport will also be an appropriate aid to them. Also, they need the reinstallation of the barangay electric system. Moreover, Manang Mareng is suggesting a provision of an elevated settlement that will serve as evacuation center during typhoons and floods.

\subsection{Rebuilding, Hard Work and "Sipag," and "Paghahandang Ispirituwal"}

Three months after the members of the Sagrada Familia temporarily settled in the evacuation center, they returned back to Ronggot a day after Christmas, on December 26, 2009. It was common story for everyone to restore things left to them. The experience was sad, however they need to struggle, to gain back the normalcy of their lives. This is the theme in the article of Inquirer.net released on January 13, 2010. According to the article,

Schools and covered courts here (Laguna Bay) are finally empty of evacuees as victims of Tropical Storms "Ondoy" and "Santi" are starting to rebuild their homes. The only evacuees left—153 families - are staying in temporary shelters donated by the Swiss government, while others have rented apartments or are staying with relatives, said municipal social welfare officer Anastacia Erasga. Some families have begun rebuilding their homes as the flood has receded in lakeshore areas, she said.

The homecoming of the members of Sagrada Familia was a blissful moment for them. The three-month long stay in the bakwetan is so far their longest experience, thus they have natural instinct to return back home. They have always been longing for this moment; to save them from the shame of using the school as evacuation center and disrupting teachers and students in their classes. I pondered on the impact of the storm Ondoy on the livelihood of the people in Ronggot. They were able to recover in a short span of time; they have now regained their normal source of living. According to Betty, the people in Ronggot are masisipag or hardworking; they are now again into fishing and water spinach farming. Manong Eufemio proudly shared to me the recovery of their water spinach plantation after two months from the time they returned back to Ronggot. These interview accounts clearly present the struggle and hard work that they need to take in order to surpass the effects of Ondoy.

In other interviews, the response to the effects of the storm Ondoy is viewed differently by the members of Sagrada Familia. On another level, the Rizalistas believe that the storm and flooding are not environmental and natural disaster but rather a spiritual phenomenon. Being such, it implies to address the problem in spiritual sense. According to Manang Gloria and Manang Bebeng, we need paghahandang ispirituwal or spiritual preparation. For them the phenomena of storm and flooding are signs for the end of the world. The motion of the environment signals the coming of the "third eye" which is the dissolution of the universe. This is a premonition to those who lost their faith in God.

\section{Conclusion}

Constructivism is a practical lens in the analysis of Ondoy as a social phenomenon. This study establishes an argument that a phenomenon can be viewed away from an objective standpoint. Through a panoptic gaze of Ondoy, this study capitalizes on the perspective that a phenomenon is socially constructed and dependent on social context. 
It anchors on the multiplicity of meanings as theoretical premise. This study proves that Ondoy means differently to the members of Sagrada Familia and Inquirer.net. The concepts elicited through this study include: natural calamity and mishap, and sakuna; disaster or tragedy and trahedya; evacauation and bakwet; assistance and tulong; and struggle, hardwork, and sipag, and paghahandang ispirituwal. The concepts used by the members of Sagrada Familia and Inquirer.net may have semblance but in deeper sense, the nuances are different. The Filipino terms encompass the uniqueness of the experiences from the perspective of the Sagrada Familia members. This poses significant implication to the process of designing appropriate responses and interventions to the problem. At the level of program design, deep understanding of the storm Ondoy will be significant in formulating practical, problem specific, community-based, and participatory approaches of community engagement.

In theorizing, this study demonstrates the applicability of constructivism as theoretical frame in the analysis of the storm Ondoy in the context of the members of Sagrada Familia and Inquirer.net. Also, in methodology, this study exhibits the use of mixed qualitative methods in data gathering. The use of triangulation in this study sharpens the description of Ondoy as a social phenomenon. Through the use of in-depth interviews, review of articles and observation, the meaning of Ondoy was broadly captured and described.

\section{References}

Cinco, Maricar. (2009). Distribution of medicine vs leptospirosis in flooded Laguna town eyed. Retrieved March 21, 2010, from http://newsinfo.inquirer.net/breakingnews/regions/view/20091016-230404/Distribution-of-medicine-vs-lept ospirosis-in-flooded-Laguna-town-eyed

Cinco, Maricar, \& Marlon Ramos. (2009). Laguna Lake rising to critical level. Retrieved March 21, 2010, from http://newsinfo.inquirer.net/inquirerheadlines/nation/view/20091004-228271/Laguna-Lake-rising-to-critical -level

David, Rina Jimenez. (2009). Ondoy': Counting costs and blessings. Retrieved March 21, 2010, from http://opinion.inquirer.net/inquireropinion/columns/view/20091009-229121/Ondoy-Counting-costs-and-ble ssings

Dizon, Nikko. (2009). Ondoy intensifies into storm; alerts up. Retrieved March 21, 2010, from http://newsinfo.inquirer.net/breakingnews/metro/view/20090925-226893/Ondoy-intensifies-into-storm-alert s-up

Dizon, Nikko. (2009). 'Ondoy' victims' relocation to take a year-DSWD chief. Retrieved March 21, 2010, from http://newsinfo.inquirer.net/breakingnews/nation/view/20091010-229356/Ondoy-victims-relocation-to-take -a-yearDSWD-chief

Evangelista, Katherine. (2009). 73 dead, more than 300,000 displaced by Ondoy. Retrieved March 21, 2010, from http://newsinfo.inquirer.net/breakingnews/nation/view/20090927-227130/51-dead-280000-displaced-by-On doy

Lapitan, Karen. (2009). 1 dead, 3,000 families evacuated in Calamba City. Retrieved March 21, 2010, from http://newsinfo.inquirer.net/breakingnewsregions/view/20090929-227479/1-dead-3000-families-evacuatedin-Calamba-City

Mallari, Delfin. (2009). Ondoy brings windfall to lake fishers. Retrieved March 21, 2010, from http://newsinfo.inquirer.net/topstories/topstories/view/20091005-228418/Ondoy-brings-windfall-to-lake-fis hers

Olchondra, Riza T. (2009). Ondoy destroys P95M in crops in Calabarzon. Retrieved March 21, 2010, from $\mathrm{http} / / /$ business.inquirer.net/money/breakingnews/view/20090928-227277/Ondoy-destroys-P95M-in-crops-i n-Calabarzon

Palumbarit, Clarice Colting. (2009). Duck pens shelter Laguna town evacuees. Retrieved March 21, 2010, from http://newsinfo.inquirer.net/inquirerheadlines/regions/view/20091119-237223/Duck-pens-shelter-Laguna-to wn-evacuees

Perry, Ronald, \& E. L. Quarantelli (Eds.). (2005). What is a disaster? United States of America: International Research Committee on Disasters.

Ritzer, George. (1996). Sociological Theory. New York: McGraw-Hill Companies.

Tandoc, Edson C., \& Katherine Evangelista. (2009). Floods submerge Metro Manila areas As Typhoon Ondoy batters Luzon. Retrieved March 21, 2010, from 
http://newsinfo.inquirer.net/breakingnews/nation/view/20090926-227047/Floods-submerge-Metro-Manila-a reas-as-typhoon-Ondoy-batters-Luzon

Uy, Jocelyn. (2009). Laguna de Bay rising; lakeside towns warned. Retrieved March 21, 2010, from http://newsinfo.inquirer.net/breakingnewsregions/view/20091002-228051/Laguna-de-Bay-rising-lakeside-t owns-warned

(2009). Ondoy death toll climbs to 280. Retrieved March 21, 2010, from http://newsinfo.inquirer.net/breakingnews/nation/view/20091001-227890/Ondoy-death-toll-climbs-to-280

- (2009). EU gives another P490M to Ondoy-Pepeng victims. Retrieved March 21, 2010, from http://globalnation.inquirer.net/news/breakingnews/view/20091122-237718/EU-gives-another-P490M-to-O ndoy-Pepeng-victims 